\title{
Temporal origins and diversification of Artemisia and allies (Anthemideae, Asteraceae)
}

\author{
M. SANZ ${ }^{1,3}$, G. M. SCHNEEWEISS ${ }^{2}$, R. VILATERSANA ${ }^{3}$ \& J. VALLÈS ${ }^{1}$ \\ ${ }^{1}$ Laboratori de Botànica, Facultat de Farmàcia, Universitat de Barcelona, Av. Joan XXII s/n., E-08028 Barcelona, Catalonia, Spain \\ ${ }^{2}$ Department of Systematic and Evolutionary Botany, University of Vienna, Rennweg 14, 1030 Vienna, Austria \\ ${ }^{3}$ Institut Botànic de Barcelona (IBB-CSIC-ICUB), Psg. del Migdia s/n., Parc de Montjuïc, E-08038 Barcelona, Catalonia, Spain
}

Author for correspondence: M. Sanz (mariasanz@ub.edu)

Editor: M. Galbany Casals

Received 14 January 2011; Accepted 15 March 2011

\begin{abstract}
Temporal origins and diversification of Artemisia and allies (Anthemideae, Asteraceae).- To assess temporal origins and diversification of lineages within subtribe Artemisiinae and Artemisia group a penalized likelihood analysis was applied on nrDNA ITS and ETS of 63 representatives. The tree was calibrated at the stem node of the Kaschgaria/ Artemisia lineage with the most reliable early Artemisia fossil pollen record from Late Oligocene (23 Ma). The results from this study suggest that the origin of the subtribe goes back to the Late Oligocene (24.6 $\pm 2.6 \mathrm{Ma})$ whilst the onset of differentiation of the genus Artemisia and most closely related genera is dated to the Early Miocene (19.8 $\pm 2.3 \mathrm{Ma})$. Divergence ages for lineages within the Artemisia group are often between the Early and Middle Miocene, whereas their radiations mostly occurred in the Late Miocene and Pliocene. The temporal context was also used to examine biogeographic and morphological (capitula and pollen type) evolution. Within the Artemisia group all lineages except the North American endemic have colonized the Mediterranean Basin at different epochs from Asian ancestors. Our analyses suggest the divergence of the North American endemic group from Asian ancestors (10.8 $\pm 1.5 \mathrm{Ma})$ in the Late Miocene. Homogamous-discoid capitula, characteristic of subgenera Seriphidium and Tridentatae, evolved not only in different geographic regions, but also at different times (2.0 $\pm 0.8 \mathrm{Ma}$ and $7.9 \pm 0.9 \mathrm{Ma}$ respectively) within the Artemisia group. The loss of fertility of central flowers of disciform capitula should be considered as an ancient event in the genus since subgenus Dracunculus is one of the first groups that diverged $(17.6 \pm 2.1 \mathrm{Ma})$
\end{abstract}

Key words: Anthemideae; Artemisia; Artemisiinae; biogeography; Compositae; molecular dating; morphological evolution.

\section{Resumen}

Evolución temporal y diversificación en Artemisia y géneros relacionados (Anthemideae, Asteraceae).- Con el objetivo de estimar el tiempo de diversificación de los linajes de la subtribu Artemisiinae y el grupo Artemisia se aplicó un análisis de verosimilitud penalizado en base a las secuencias de ADNrn, ITS y ETS, de 63 representantes. El árbol se calibró en el nodo del linaje de Kaschgaria/Artemisia con el polen fósil de Artemisia que se consideró más fiablemente datado, siendo esta datación del Oligoceno Superior (23 Ma). Los resultados de este estudio datan el origen de la subtribu en el Oligoceno Superior (24,6 $\pm 2,6 \mathrm{Ma})$, mientras que la diferenciación del género Artemisia y los géneros relacionados es datada en el Mioceno Inferior (19,8 $\pm 2,3 \mathrm{Ma}$ ). El tiempo de divergencia de los linajes dentro del grupo Artemisia está situado entre el Mioceno Inferior y el Medio, mientras que la mayoría de sus radiaciones tuvieron lugar en el Mioceno Superior y en el Plioceno. El contexto temporal también se usó para examinar la evolución biogeográfica y morfológica (tipo de capítulo y polen). Todos los linajes dentro del grupo de Artemisia, excepto el complejo endémico norteamericano, han colonizado la cuenca mediterránea en diferentes épocas. Nuestros análisis sugieren la divergencia del grupo endémico norteamericano de antepasados asiáticos (10,8 \pm 1,5 Ma) en el Mioceno Superior. El capítulo homógamo-discoide, característico de los subgéneros Seriphidium y Tridentatae, evolucionó no sólo en diferentes regiones geográficas, sino también en distintas épocas (2,0 $\pm 0,8$ Ma y 7,9 $\pm 0,9$ Ma respectivamente) dentro del grupo Artemisia. La pérdida de fertilidad de las flores centrales del capítulo disciforme se debería considerar como un evento antiguo en el género, puesto que el subgénero Dracunculus es uno de los primeros grupos que divergió (17,6 $\pm 2,1 \mathrm{Ma})$.

Palabras clave: Anthemideae; Artemisia; Artemisiinae; biogeografía; Compositae; datación molecular; evolución morfológica. 


\section{INTRODUCTION}

Artemisia L. is the largest and most diverse genus of the tribe Anthemideae (Asteraceae) comprising more than 500 taxa at the specific or subspecific level (Vallès \& Garnatje, 2005 and references therein). It is a cosmopolitan genus, mainly distributed in temperate areas of the northern hemisphere colonizing mainly arid and semiarid environments, from sea level to high altitudes, with only a few representatives in the southern hemisphere (Pellicer et al., 2010). Central Asia is the main centre of diversification, secondary ones being the Mediterranean region and Northwest America (McArthur \& Plummer, 1978; Vallès \& McArthur, 2001). Currently, five subgenera are distinguished, mostly based on floral characters: Absinthium DC., Artemisia, Dracunculus Besser, Seriphidium Besser and Tridentatae (Rydb.) McArthur (see Table 1 in Torrell et al., 1999).

Bremer \& Humphries (1993) included Artemisia in subtribe Artemisiinae, which additionally comprises 17 allied or segregated genera. The latest phylogenetic studies (Oberprieler et al., 2007, 2009; Sanz et al., 2008; Tkach et al., 2008a) prove that the genus Artemisia in the circumscription of Bremer \& Humphries (1993) is paraphyletic because Crossostephium Less., Filifolium Kitam., Mausolea Bunge, Neopallasia Poljakov, Picrothamnus Nutt., Sphaeromeria Nutt. and Turaniphytum Poljakov are nested within Artemisia. These studies also prove that the subtribe, in order to be monophyletic, should also include some genera placed by Bremer \& Humphries (1993) in other subtribes: Hippolytia Poljakov (Tanacetinae), Leucanthemella Tzvelev and Nipponanthemum Kitam. (both Leucantheminae).

Traditionally, pollen type (see Martín et al., 2001, 2003 for references) and capitula (Besser, 1829, 1832, 1834, 1835; Candolle, 1837) have been considered as important characters for generic and infrageneric circumscription of Artemisia, respectively. Pollen morphological data (Martín et al., 2001, 2003; Pellicer et al., 2009) confirm the coexistence of two pollen patterns in subtribe Artemisiinae: the Anthemis-type with conspicuous spines (echinate pollen), and the Artemisia-type, with spinules (microechinate pollen). Martín et al. (2001, 2003) determined that ornamentation with short spinules is a good taxonomic marker for Artemisia and closely related genera. According to Sanz et al. (2008), the ancestral condition in the subtribe was discoid capitula arranged solitarily or in laxly corymbose synflorescences with Anthemis pollen type, whereas the ancestor of the Artemisia-Kaschgaria clade had disciform capitula (with central hermaphrodite florets) arranged in densely corymbose synflorescences, with Artemisia pollen type.

The first appearance of Artemisia has been widely discussed (Miao et al., 2011 and references therein). Pollen fossil records suggest that Artemisia originated in temperate Asia during the Late Eocene (Miao et al., 2011) or the Mid-Tertiary (Wang, 2004). According to Wang (2004), there are two reliable fossil pollen records of Artemisia in China, one from the Early Oligocene in Xinjiang province (Song, 1965), the second from the Late Oligocene in the Qinghai province (Zhu et al., 1985; Miao et al., 2011). The age of the rocks for both places was originally determined by biostratigraphic evidence, but that of the Qinghai province was later adjusted by paleomagnetic data (CGTRP, 1992). The most ideal data are the fossil pollen sites with reliable paleomagnetic dating and high percentages of Artemisia pollen (Miao et al., 2011), therefore we considered the Late Oligocene date (Zhu et al., 1985) the most reliable early Artemisia fossil pollen record. Following Ling (1991a, 1991b, 1994), the putative ancestor of Artemisia existed in Northern Asia and the migrations from this place supposedly occurred along three lines: (1) westward into Europe, Western Asia, Asia Minor, the Mediterranean Basin, and Africa; (2) eastward into Siberia and into Western North America, and (3) further South into Asia.

The use of DNA sequences to estimate the timing of evolutionary events is increasingly popular. In plants, molecular dating has been used in numerous studies to investigate the timeframe of evolutionary events, e.g. for testing biogeographical hypotheses or to investigate the causes of recent radiations (reviewed in Sanderson et al., 2004). Dating techniques have been applied on taxa from very different taxonomic levels, e.g. angiosperms (Magallón \& Sanderson, 2001; Wikström et al., 2001; Bell et al., 2005), Compositae (Funk et al., 2009), genera or species level (Park et al., 2006; Smith et al., 2008; Goodall-Copestake et al., 2009). Oberprieler (2005) estimated temporal evolution of the tribe Anthemideae based on ITS sequences. In 
Artemisia, Tkach et al. (2008b) dated the origins of Arctic lineages of the genus using a Bayesian approach with an uncorrelated lognormal clock on molecular ETS and ITS data. However, none of them have dealt with temporal evolution of lineages within the subtribe Artemisiinae and/or within the Artemisia group.

Therefore, the main goals of this study are (1) to assess temporal origins and diversification of the group, and (2) to examine biogeographic and morphological (capitula and pollen type) evolution of the group using this temporal context.

\section{MATERIALS AND METHODS}

\section{Data set}

For the reconstruction of the temporal evolution of the group presented here we use the same data set as in our previous study (Sanz et al., 2008) that comprises sequence information for nrDNA ITS and ETS for 63 representatives of the subtribe. The data set consists of 45 species of Artemisia (46 populations) representing all five traditional subgenera and the geographical range of the genus, and 14 species from 13 genera belonging to subtribe Artemisiinae (Ajania Poljakov, Brachanthemum DC., Dendranthema (DC.) Des Moul., Elachanthemum Y. Ling \& Y.R. Ling, Filifolium, Kaschgaria Poljakov, Mausolea, Neopallasia, Picrothamnus, Sphaeromeria, Turaniphytum, Nipponanthemum nipponicum Kitam. and Hippolytia megacephala (Rupr.) Poljakov.

\section{Divergence time estimation}

We used the most accurately dated and thus most reliable early Artemisia fossil pollen found in the Late Oligocene in the Qinghai province (Zhu et al., 1985) as calibration point. The age of this fossil cannot be assigned to any of the species within the Artemisia group and, hence, it can only be used to suggest a minimum age for Artemisia and closely related genera with Artemisia pollen type. Considering the appearance of microechinate pollen in the lineage leading to Elachanthemum intricatum (Franch.) Y. Ling \& Y.R. Ling as a convergence, the most suitable calibration point (Magallón, 2004) would be the stem node of Kaschgaria/Artemisia lineage. Consequently, we fixed the age of the stem node of this clade at 23 million years ago (Ma), i.e. the Oligocene-Miocene boundary.

Previous maximum likelihood (ML) analysis to infer tree topologies and branch lengths from the combined dataset was employed (Sanz et al., 2008). Likelihood ratio test (LRT; Felsenstein, 1988) for rate constancy indicated that neither ITS nor ETS evolved in a clock-like manner. Hence, to obtain ultrametric trees we applied penalized likelihood (PL; Sanderson, 2002) as implemented in r8s 1.7 (Sanderson, 2003) to estimate minimum ages of the most recent common ancestor (MRCA) of selected nodes. PL is a semiparametric method that allows substitution rates to vary among lineages according to a smoothing parameter. The optimal smoothing parameter was chosen on the basis of the data by cross-validation (Sanderson, 2003). Confidence intervals were calculated by data bootstrapped 100 times. We generated 100 phylograms topologically identical, but with different branch length and then was summarized age distribution for each particular node. The central $95 \%$ of the age distribution provides an interval of confidence (Sanderson \& Doyle, 2001). Bootstrap data matrices were generated using the Seqboot program in Phylip package (Felsenstein, 1999). First, we obtained relative ages by arbitrarily setting the root age to an age of 100 , which were subsequently translated into absolute ages by calibrating the stem node of the Kaschgaria/Artemisia lineage to 23 Ma based on fossil pollen record. All divergence time estimates are given in $\mathrm{Ma}$ and were placed into the current timescale for the Cenozoic based on the International Union of Geological Sciences 2009 (IUGS) (Gibbard et al., 2009). The ultrametric tree was visualized in the program FigTree ver. 1.1.2 (Rambaut \& Drummond, 2007).

\section{RESULTS}

Likelihood ratio test for rate constancy rejected the assumption of a molecular clock for both data sets $(p<0.001)$. Cross-validation analyses identified the optimal smoothing parameter for the combined data set as 2. Average divergence times plus standard deviations for selected nodes in the ML combined tree are given in Table 1 and the chronogram obtained is shown in Fig. 1. 
Table 1. Average divergence times ( \pm standard deviation) in Ma of selected nodes (their designation by letters used in Fig. 1 is given in parentheses).

\begin{tabular}{|lr|}
\hline Most recent & $\begin{array}{r}\text { Divergence times } \\
\text { common ancestor of... }\end{array}$ \\
\hline Artemisiinae (A) & $24.6 \pm 2.6$ \\
Nipponanthemum clade (B) & $12.1 \pm 3.2$ \\
Dendranthema group (C) & $4.3 \pm 1.2$ \\
Kaschgaria/Artemisia lineage (D) & $21.6 \pm 2.4$ \\
Artemisia group (E) & $19.8 \pm 2.3$ \\
Subgenus Dracunculus (F) & $17.6 \pm 2.1$ \\
Alpine/Mediterranean split (G) & $6.8 \pm 0.8$ \\
Artemisia absinthium complex (H) & $5.9 \pm 1.5$ \\
Alpine group (I) & $5.8 \pm 0.8$ \\
Artemisia afra clade (J) & $6.6 \pm 1.6$ \\
Subgenus Seriphidium (K) & $2.0 \pm 0.8$ \\
North American group/A. vulgaris complex (L) & $10.8 \pm 1.5$ \\
North American group (M) & $7.9 \pm 0.9$ \\
Artemisia vulgaris complex (N) & $7.8 \pm 1.3$ \\
\hline
\end{tabular}

Molecular clock analyses suggest that subtribe Artemisiinae diversified at least $24.6 \pm 2.6 \mathrm{Ma}$ (node A), whereas the Artemisia group diverged from its sister Kaschgaria group at 21.6 $\pm 2.4 \mathrm{Ma}$ (node D). In the basal groups, the diversification of the Dendranthema group and of the Nipponanthemum clade was estimated at $4.3 \pm 1.2 \mathrm{Ma}$ (node $\mathrm{C}$ ) and $12.1 \pm 3.2 \mathrm{Ma}$ (node B), respectively. Within the Artemisia group, the oldest lineage was subgenus Dracunculus (node F: $17.6 \pm 2.1 \mathrm{Ma}$ ) and the youngest subgenus Seriphidium (node K: $2.0 \pm 0.8 \mathrm{Ma}$ ). Other noteworthy divergence ages are the split of the North American endemic group from the Eurasian species (node L: $10.8 \pm 1.5 \mathrm{Ma}$ ), the diversification of the alpine group (node I: $5.8 \pm 0.8 \mathrm{Ma}$ ), the diversification of the $A$. absinthium L. complex (node $\mathrm{H}$ : $5.9 \pm 1.5 \mathrm{Ma}$ ) and the split of $A$. afra Jacq. from $A$. santolinifolia Turcz. ex Besser (node J: 6.6 $\pm 1.6 \mathrm{Ma}$ ).

\section{DISCUSSION}

\section{Temporal diversification}

Following the calibration of the present tree (Fig. 1), the origin of the subtribe in Asia goes back to the Late Oligocene (node A: $24.6 \pm 2.6 \mathrm{Ma}$ ) whilst the onset of differentiation of the genus Artemisia and most closely related genera is dated to the Early Miocene (node E: $19.8 \pm 2.3 \mathrm{Ma}$ ). Divergence ages for the main lineages within the Artemisia group correspond mainly to the Early or Middle Miocene, whereas their radiations mostly occurred in the Late Miocene and Pliocene.

Oberprieler (2005) reported the divergence time of subtribe Artemisiinae to be 7-10 Ma (Late Miocene) based on a molecular clock analyses of the tribe Anthemideae using ITS sequences. However, our dating estimates suggest that Artemisia fossil pollen was sparsely distributed during the Early Miocene, and widely distributed during the Late Miocene, being particularly abundant during the Pliocene and the Pleistocene (Wang, 2004; Song et al., 2004; Miao et al., 2011). Furthermore, the present results are consistent with geologic and ecological changes during the Late Tertiary in Asia (Axelrod et al., 1996), specifically with the onset of increased aridity in Asian climate by at least $22 \mathrm{Ma}$ (as evidenced by paleomagnetic data) due to regional tectonic changes and the uplift of the Tibetan-Himalayan complex (Guo et al., 2002).

The dry conditions in Central Asia and the strong cooling of the Late Eocene, partly related to the above-mentioned tectonic events, probably favoured the Artemisia expansion (Miao et al., 2011). A similar pattern of explosive radiation in the Qinghai-Tibetan plateau within the last $20 \mathrm{Ma}$ has been reported for other Asteraceae groups (Ligularia-CremathodiumParasenecio complex; Liu et al., 2006).

According to our reconstructions, within the Artemisia group all lineages except the North American endemic group have colonized the Mediterranean

\footnotetext{
Figure 1. Chronogram of Artemisia and allied genera based on penalized likelihood analysis of a maximum likelihood tree constructed from combined nrDNA ITS and ETS data. Posterior probability values (above) and bootstrap supports (below) derive from our previous study (Sanz et al., 2008). To calibrate the tree, the stem node of the clade including Artemisia and Kaschgaria was fixed to $23 \mathrm{Ma}$. Nodes, for which ages were estimated, are indicated by capital letters. Geological epochs are abbreviated as follows: Plio, Pliocene; Pleis, Pleistocene. Capitula types are mapped in different colors and taxa with Anthemis-type pollen are shown in grey.
} 


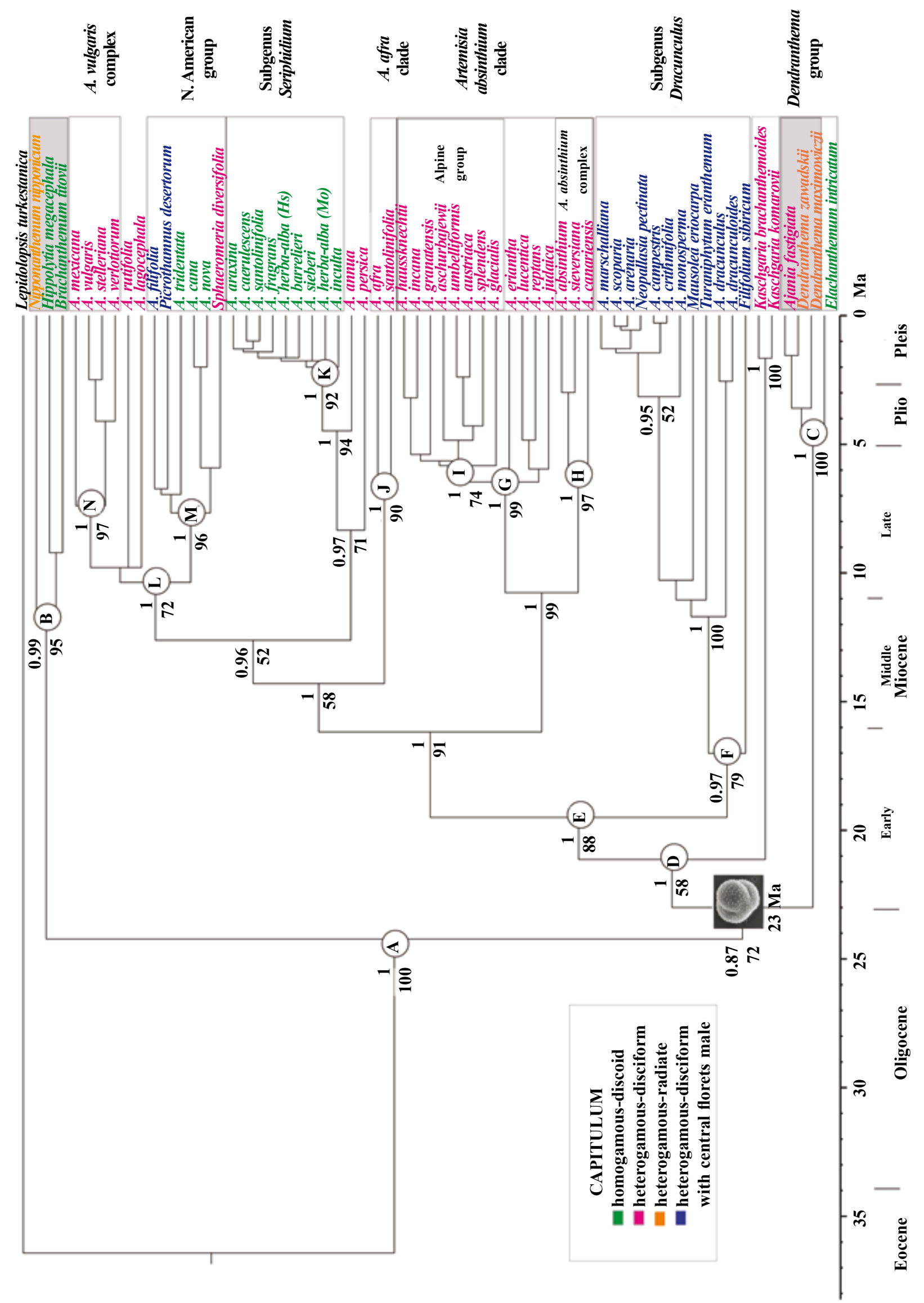


Basin at different epochs from Asian ancestors. The first colonization of this area took place in the Late Miocene during the Messinian salinity crisis (5.96$5.33 \mathrm{Ma}$ ), when the closure of the MediterraneanAtlantic gateways caused the nearly completely evaporation of the Tethys sea (Hsü et al., 1973; Bocquet et al., 1978; Meulenkamp \& Sissingh, 2003) and the progressive aridification of this region (Van Dam, 2006). Examples include Eastern and Western Mediterranean species (A. judaica L., A. reptans C. Sm. ex Link and A. lucentica O. Bolòs, Vallès-Xirau $\&$ Vigo) within the Artemisia/Absinthium clade (node G: $6.8 \pm 0.8 \mathrm{Ma}$ ) and the ancestor leading to the $A$. absinthium complex (node $\mathrm{H}: 5.9 \pm 1.5 \mathrm{Ma}$ ). Later on, at the end of Pliocene there was a secondary colonization of the Mediterranean region by members of the subgenera Dracunculus (A. campestris L., A. monosperma Delile) and Seriphidium (A. barrelieri Besser, A. herba-alba Asso, A. inculta Delile). The dramatic changes experienced in the Mediterranean climate from 3.5 Ma onwards, with the stabilization of summer drought (Suc, 1984; Thompson, 2005) could facilitate the latter colonizations.

A westward colonization of the Mediterranean Basin is a common trend in plants (Paun et al., 2005; Mráz et al., 2007) and has been also described in other Anthemideae groups (Lo Presti \& Oberprieler, 2009).

Our dating results show that the divergence of $A$. canariensis Less. from its continental sister species (node H: $5.9 \pm 1.5 \mathrm{Ma}$ ), and the split of Central Asian A. santolinifolia from the South African A. afra (node J: $6.6 \pm 1.6 \mathrm{Ma}$ ) date back to Late Miocene. These estimates are consistent with the increase of land bridges in the Mediterranean during the Late Miocene (Meulenkamp \& Sissingh, 2003) that also could have provided migration routes of the Eurasian flora into Africa and Macaronesia as described in several other plant groups (Oberprieler, 2005; Mansion et al., 2008).

Our analyses suggest two arrivals to North America in the Late Miocene. One concerns the divergence of the North American endemic group from Asian ancestors (node L: $10.8 \pm 1.5 \mathrm{Ma}$ ) and the other the diversification of the American endemic A. mexicana Willd. from its Eurasian vicariants of the A. vulgaris L. complex (node N: $7.8 \pm 1.3 \mathrm{Ma}$ ). Tkach et al. (2008b), based on uncorrelated lognormal clock method and calibrating the tree at the Eocene/Oligocene boundary (34 Ma), obtained a similar divergence age of these groups (median age: 13.5 Ma and 7.5 Ma respectively). Floristic exchanges between Asia and North America were most likely across the Bering and the North Atlantic land bridges (Tiffney, 1985; Wen, 1999). The Beringian Land Bridge began to cool down from the Middle Miocene (15 Ma) onwards with an increasing cooling trend in the Late Miocene (Mosbrugger et al., 2005; Milne, 2006) that would have favoured vicariance of Old and New world Artemisia species. In addition, our estimated age is consistent with a Middle Miocene (12 Ma) development of the sagebrush steppe in the Great Basin cold desert in North West America (Davis \& Ellis, 2010).

Our age estimates suggest an origin of the alpine group in the Late Miocene (node I: $5.8 \pm 0.8 \mathrm{Ma}$ ) and its diversification in the Pliocene. At that time, the old-tertiary Alpine orogeny had already formed the main European mountain belts (Smith et al., 1994). This finding supports the origin of orophytic groups within the genus earlier than Quaternary glaciations. Similar conclusions have been drawn for other European alpine taxa (Comes \& Kadereit, 2003; Paun et al., 2005).

Regarding temporal evolution of morphological traits, in the basal groups the divergence of the monotypic genus Nipponanthemum (node B: $12.1 \pm 3.2 \mathrm{Ma}$ ) is a relatively ancient event in the subtribe compared to that of the Dendranthema species (node C: $4.3 \pm 1.2 \mathrm{Ma}$ ). Therefore, the origin of radiate capitula and Anthemis pollen-type (both characters only found together in these two genera among the studied ones) occurred in different periods of time during the evolution of the subtribe. The reconstruction of the capitula type evolution within the Artemisia group (Sanz et al., 2008) suggests that all capitula types evolved from heterogamousdisciform capitula with central hermaphrodite and outer female, non radiate florets. Our age estimates indicate that Dracunculus (heterogamous-disciform capitula with central florets male) is one of the first groups that diverged (node F: $17.6 \pm 2.1 \mathrm{Ma}$ ), therefore the loss of fertility of central florets of disciform capitula should be considered as an ancient event in the genus. In contrast, subgenus Seriphidium is the youngest group within Artemisia (node K: $2.0 \pm 0.8 \mathrm{Ma}$ ) and it diverged independently of the North American subgenus Tridentatae that diverged approximately 6 million years earlier (node M: $7.9 \pm 0.9$ ). This implies that homogamous- 
discoid capitula (with all florets hermaphrodite), characteristic for both subgenera, evolved not only in different geographic regions, but also at different times within the Artemisia group.

Similarly, the evolution of the heterogamous capitula with male central florets, found in the lineage that gave rise to subgenus Dracunculus from perfect heterogamous capitula (Sanz et al., 2008) also arose in different periods in Asia and North America (Artemisia filifolia Torrey and the monotypic genus Picrothamnus).

\section{CONCLUDING REMARKS}

The results of this research suggest that the divergence ages for the main lineages within the Artemisia group chiefly correspond to the Early and Middle Miocene, whereas the radiation of the groups occurred mostly in the Late Miocene and Pliocene.

Our analyses suggest that all lineages, except the North American endemic group, have colonized the Mediterranean Basin at different epochs from Asian ancestors. The loss of fertility of central florets in Dracunculus from perfect heterogamous capitula is dated as an ancient event in the genus.

The scarce fossil data and the need of a broader sampling warrant caution in the interpretation of the molecular dating results, and further studies will be necessary to test our temporal hypotheses.

\section{ACKNOWLEDGEMENTS}

This study was subsidized by projects CGL2004-04563-C02-02/ BOS of the Spanish government and the 2009/SGR/439 of the Generalitat de Catalunya. The first author received a predoctoral grant and support to perform a stay in the Botanical Garden of Vienna from the Spanish Government (FPI program). Víctor Suárez and an anonymous reviewer are thanked for their comments, which improved the manuscript.

\section{REFERENCES}

Axelrod, D. I., Al-Shehbaz, I. \& Raven, P. H. 1996. History of the modern flora of China. In: Zhang, A. L. \& Wu, S. G. (Eds.), Floristic Characteristics and Diversity of East Asian Plants. China Higher Education Press, Beijing, SpringerVerlag, Berlin: 43-55.

Bell, C. D., Soltis, D. E. \& Soltis, P. S. 2005. The age of the angiosperms: a molecular timescale without a clock. Evolution 59: 1245-1258.

Besser, W. S. J. G. 1829. Synopsis Absinthiorum. Bull. Soc. Imp. Naturalistes Moscou 1: 219-265.
Besser, W. S. J. G. 1832. Tentamen de Abrotanis seu de sectione IIda Artemisiarum Linnaei. Bull. Soc. Imp. Naturalistes Moscou 3: 1-92.

Besser, W. S. J. G. 1834. De Seriphidiis seu de sectione IIIa Artemisiarum Linnaei. Bull. Soc. Imp. Naturalistes Moscou 7: 1-46.

Besser, W. S. J. G. 1835. Dracunculi seu de sectione IVta et ultima Artemisiarum Linnaei. Bull. Soc. Imp. Naturalistes Moscou 8: 1-95.

Bocquet, G., Widler, B. \& Kiefer, H. 1978. The Messinian model. A new outlook for the floristics and systematics of the Mediterranean area. Candollea 33: 269-287.

Bremer, K. \& Humphries, C. 1993. Generic monograph of the Asteraceae-Anthemideae. Bull. Nat. Hist. Mus., London 23: 71-177.

Candolle, A. P. de. 1837. Prodromus Systematis Naturalis Regni Vegetabilis, Pars VI. Treuttel et Würtz, Paris.

CGTRP (Coordinated Group of the Tertiary Research Project, China National Petroleum Corporation). 1992. Correlation between the Tertiary strata in oil-gasbearing areas of China and the typical sequence in Europe and America. Chin. Sci. Bull. 37: 494-496.

Comes, H. P. \& Kadereit, J. W. 2003. Spatial and temporal patterns in the evolution of the flora of the European Alpine System. Taxon 52: 451-462.

Davis, O. K. \& Ellis, B. 2010. Early occurrence of sagebrush steppe, Miocene (12 Ma) on the Snake River Plain. Rev. Palaeobot. Palynol. 160: 172-180.

Felsenstein, J. 1988. Phylogenies from molecular sequences: inference and reliability. Ann. Rev. Genet. 22: 521-565.

Felsenstein, J. 1999. Phylip ver. 3.5c. Available from: http:// evolution.genetics.washington.edu/phylip.html.

Funk, V. A., Anderberg, A. A., Baldwin, B. G. et al. 2009. Compositae metatrees: the next generation. In: Funk, V. A., Susanna, A., Stuessy, T. F. \& Bayer, R. J. (Eds.), Systematics, evolution, and biogeography of Compositae. International Association Plant Taxonomy, Vienna: 747-777.

Gibbard, P. L., Head, M. J., Walker, M. J. C. \& the Subcommission on Quaternary Stratigraphy. 2009. Formal ratification of the Quaternary System/Period and the Pleistocene Series/ Epoch with a base at 2.58 Ma. J. Quaternary Sci. 25: 96-102.

Goodall-Copestake, W. P., Harris, D. J. \& Hollingsworth, P. M. 2009. The origin of a megadiverse genus: Dating Begonia (Begoniaceae) using alternative datasets, calibrations and relaxed clock models. Bot. J. Linn. Soc. 159: 363-380.

Guo, Z. T., Ruddiman, W. F., Hao, Q. Z. et al. 2002. Onset of Asian desertification by $22 \mathrm{Myr}$ ago inferred from loess deposits in China. Nature 416: 159-163.

Hsü, K. J., Cita, M. B. \& Ryan, W. B. F. 1973. The origin of the Mediterranean evaporites. DSDP Initial Reports 13: 1203-1221.

Ling, Y. R. 1991a. The Old World Seriphidium (Compositae). Bull. Bot. Res., Harbin 11: 1-40.

Ling, Y. R. 1991b. The Old World Artemisia (Compositae). Bull. Bot. Res., Harbin 12: 1-108.

Ling, Y. R. 1994. The genera Artemisia L. and Seriphidium (Bess.) Poljak. in the world. Compositae Newslett. 25: 39-45.

Liu, J. Q., Wang, Y. J., Wang, A. L., Hideaki, O. \& Abbot, R. J. 2006. Radiation and diversification within the Ligularia-Cremanthodium-Parasenecio complex (Asteraceae) triggered by uplift of the Qinghai-Tibetan Plateau. Mol. 
Phylogenet. Evol. 38: 31-49.

Lo Presti, R. M. \& Oberprieler, C. 2009. Evolutionary history, biogeography and eco-climatological differentiation of the genus Anthemis L. (Compositae, Anthemideae) in the circum-Mediterranean area. J. Biogeogr. 36: 1313-1332.

Magallón, S. A. \& Sanderson, M. J. 2001. Absolute diversification rates in angiosperm clades. Evolution 55: 1762-1780.

Magallón SA. 2004. Dating lineages: molecular and palaeontological approaches to the temporal framework of clades. Int. J. Plant Sci. 165: 7-21.

Mansion, G., Rosenbaum, G., Schoenenberger, N., Bacchetta, G., Rosselló, J. A. \& Conti, E. 2008. Phylogenetic analysis informed by geological history supports multiple, sequential invasions of the Mediterranean Basin by the angiosperm family Araceae. Syst. Biol. 57: 269-285.

Martín, J., Torrell, M., Korobkov, A. A. \& Vallès, J. 2003. Palynological features as a systematic marker in Artemisia L. and related genera (Asteraceae, Anthemideae) II: implication for subtribe Artemisiinae delimitation. Plant Biol. 5: 85-93.

Martín, J., Torrell, M. \& Vallès, J. 2001. Palynological features as a systematic marker in Artemisia L. and related genera (Asteraceae, Anthemideae). Plant Biol. 3: 372-378.

McArthur, E. D. \& Plummer, A. 1978. Biogeography and management of the native western shrubs: A case study, section Tridentatae of Artemisia. Great Basin Nat. 2: 229-243.

Meulenkamp, J. J. \& Sissingh, W. 2003. Tertiary palaeogeography and tectonostratigraphic evolution of the Northern and Southern Peri-Tethys platforms and the intermediate domains of the African-Eurasian convergent plate boundary zone. Palaeogeogr. Palaeoclimatol. Palaeoecol. 196: 209-228.

Miao, Y., Meng, Q., Fang, X., Yan, X., Wu, F. \& Song, Ch. 2011. Origin and development of Artemisia in Asia and its implications for the uplift history of the Tibetan Plateau: a review. Quatern. Int. 236: 3-12.

Milne, R. 2006. Northern hemisphere plant disjunctions: a window on Tertiary land bridges and climate change? Ann. Bot. 98: 465-472.

Mosbrugger, V., Utescher, T. \& Dilcher, D. L. 2005. Cenozoic continental climatic evolution of Central Europe. Proc. Natl. Acad. Sci. USA 102: 14964-14969.

Mráz, P., Gaudeul, M., Rioux, D., Gielly, L., Choler, P. \& Taberlet, P. 2007. Genetic structure of Hypochaeris uniflora (Asteraceae) suggests vicariance in the Carpathians and rapid post-glacial colonization of the Alps from an eastern alpine refugium. J. Biogeogr. 34: 2100-2114.

Oberprieler, C. 2005. Temporal and spatial diversification of Circum-Mediterranean Compositae-Anthemideae. Taxon 54: 951-966.

Oberprieler, C., Vogt, R. \& Watson, L. E. 2007. Tribe Anthemideae. In: Kadereit, J. W. \& Jeffrey, C. (Eds.), Flowering Plants Vol. VIII. Eudicots. Asterales. Springer-Verlag, Berlin: 342-374.

Oberprieler, C., Himmelreich, S., Källersjö, M., Vallès, J., Watson, L. E. \& Vogt, R. 2009. Anthemideae. In: Funk, V. A., Susanna, A., Stuessy, T. F. \& Bayer, R. J. (Eds.), Systematics, evolution and biogeography of Compositae. International Association Plant Taxonomy, Vienna: 632-666.

Park, J.-M., Kovacic, S., Liber, Z., Eddie, W. M. \& Schneeweiss, G. M. 2006. Phylogeny and biogeography of isophyllous species of Campanula (Campanulaceae) in the Mediterranean area. Syst. Bot. 31: 862-880.
Paun, O., Lehnebach, C., Johansson, J. T., Lockhart, P. \& Hörandl, E. 2005. Phylogenetic relationships and biogeography of Ranunculus and allied genera (Ranunculaceae) in the Mediterranean region and in the European Alpine System. Taxon 54: 911-932.

Pellicer, J., Hidalgo, O., Garcia, S., Garnatje, T., Korobkov, A., Vallès, J. \& Martín, J. 2009. Palynological study of Ajania and related genera (Asteraceae, Anthemideae). Bot. J. Linn. Soc. 161: 171-189.

Pellicer, J., Garnatje, T., Molero, J., Pustahija, F., SiljakYakovlev, S. \& Vallès, J. 2010. Origin and evolution of the South American endemic Artemisia species (Asteraceae): evidence from molecular phylogeny, ribosomal DNA and genome size data. Austr. J. Bot. 58: 605-616.

Rambaut, A. \& Drummond, A. J. 2007. Figtree ver. 1.1.2. Available from: http:/tree.bio.ed.ac.uk/software/figtree.

Sanderson, M. J. 2002. Estimating absolutes rates of molecular evolution and divergence times: a penalized likelihood approach. Mol. Biol. Evol. 19: 101-109.

Sanderson, M. J. 2003. r8s: inferring absolute rates of molecular evolution and divergence times in the absence of a molecular clock. Bioinformatics 19: 301-302.

Sanderson, M. J. \& Doyle, J. A. 2001. Sources of error and confidence intervals in estimating the age of angiosperms from rbcL and 18S rDNA data. Am. J. Bot. 88: 1499-1516.

Sanderson, M. J., Thorne, J. L., Wikström, N. \& Bremer, K. 2004. Molecular evidence on plant divergence times. Am. J. Bot. 91: 1656-1665.

Sanz, M., Vilatersana, R., Hidalgo, O., Garcia-Jacas, N., Susanna, A., Schneeweiss, G. M. \& Vallès, J. 2008. Molecular phylogeny and evolution of floral characters of Artemisia and allies (Anthemideae, Asteraceae): evidence from nrDNA ETS and ITS sequences. Taxon 57: 66-78.

Smith, A. G., Smith, D. G. \& Funnell, B. M. 1994. Atlas of Mesozoic and Cenozoic Coastlines. Cambridge University Press, Cambridge.

Smith, J. F., Tepe, E. J., Stevens, A. C. \& Davidson, C. 2008. Placing the origin of two species-rich genera in the late Cretaceous with later species divergence in the Tertiary: A phylogenetic, biogeographic and molecular dating analysis of Piper and Peperomia (Piperaceae). Pl. Syst. Evol. 275: 9-30.

Song, Z. C. 1965. Cenozoic palynological assemblages in China. In: Song Z. C. (Ed.). Pollen and Spore Analysis. Science Press, Beijing: 221-232.

Song, Z., Wang, W. \& Huang, F. 2004. Fossil pollen records of extant angiosperms in China. Bot. Rev. 70: 425-458.

Suc, J. P. 1984. Origin and evolution of the Mediterranean vegetation and climate in Europe. Nature 307: 429-432.

Thompson, J. D. 2005. Plant Evolution in the Mediterranean. Oxford University Press, Oxford.

Tiffney, B. H. 1985. Perspectives on the origin of the floristic similarity between eastern Asia and eastern North America. J. Arnold Arbor. 66: 73-94.

Tkach, N. V., Hoffmann, M. H., Röser, M., Korobkov, A. A. \& von Hagen, K. B. 2008a. Parallel evolutionary patterns in multiple lineages of arctic Artemisia L. (Asteraceae). Evolution 62: 184-198.

Tkach, N. V., Hoffmann, M. H., Röser, M. \& von Hagen, K. B. 2008b. Temporal patterns of evolution in the Arctic explored in Artemisia L. (Asteraceae) lineages of different age. Pl. Ecol. Div. 1: 161-169. 
Torrell, M., Garcia-Jacas, N., Susanna, A. \& Vallès, J. 1999. Infrageneric phylogeny of the genus Artemisia L. (Asteraceae, Anthemideae) based on nucleotide sequences of nuclear ribosomal DNA internal transcribed spacers (ITS). Taxon 48: 721-736

Vallès, J. \& Garnatje, T. 2005. Artemisia and its allies: genome organization and evolution and their biosystematic, taxonomic and phylogenetic implications in the Artemisiinae and related subtribes (Asteraceae, Anthemideae). In: Sharma, A. (Ed.), Plant genome: Biodiversity and Evolution. Vol. 1B: Phanerogams. Science Publishers, Enfield: 255-285.

Vallès, J. \& McArthur, E. D. 2001. Artemisia systematics and phylogeny: cytogenetic and molecular insights. In: McArthur, E. D. \& Fairbanks, D. J. (Eds.), Shrubland ecosystem genetics and biodiversity: proceedings. Rocky Mountain Research Station, Provo: 67-74.
Van Dam, J. A. 2006. Geographic and temporal patterns in the late Neogene (12-3 Ma) aridification of Europe: the use of small mammals as paleoprecipitation proxies. Palaeogeogr. Palaeoclimatol. Palaeoecol. 238: 190-218.

Wang, W. 2004. On the origin and development of Artemisia (Asteraceae) in the geological past. Bot. J. Linn. Soc. 145: 331-336.

Wen, J. 1999. Evolution of eastern Asian and eastern North American disjunct distributions in flowering plants. Ann. Rev. Ecol. Syst. 30: 421-455.

Wikström, N., Savolainen, V. \& Chase, M. W. 2001. Evolution of the angiosperms: calibrating the family tree. Proc. R. Soc. Lond. (Biol.) 268: 2211-2220.

Zhu, Z. H., Wu, L. Y., Xi, P., Song, Z. C. \& Zhang, Y. Y. 1985. A Research on Tertiary Palynology from the Qaidam Basin, Qinghai Province. The Petroleum Industry Press, Beijing. 